\title{
Implementing the Policy to Serve Citizens (BMW) in Tulang Bawang Regency: Public Service Innovation Study
}

\author{
Winarti $^{1}$, Murtir Jeddawi ${ }^{2}$, Sampara Lukman $^{3}$, Agus Fatoni $^{4}$ \\ ${ }_{1,2,3,4}$ Institut Pemerintahan Dalam Negeri (IPDN), Indonesa \\ Email: winartitulang1@gmail.com
}

\begin{abstract}
This study examines the implementation of the "Move to Serve Citizens" (BMW) policy in assessing innovation in public services in Tulang Bawang Regency, Lampung Province. Government leadership in implementing the "Move to Serve Citizens" (BMW) policy was initiated in the RANPERDA RPJMD Tulang Bawang 2017-2024 which is also an arrangement to realize its vision-mission of regional heads to improve community welfare and optimal public services in Tulang Bawang district. Research on the implementation of mobile policies to serve residents in Tulang Bawang Regency (the study of public service innovation uses a mixed-method research type or is often referred to as a mixed method, a research approach that combines associates qualitative and quantitative forms with inductive-deductive thought processes. BMW policy has a significant effect on public services. The research findings revealed that the BMW policy variable, each indicator of this variable, is considered to determine the success of the policy objectives. It has been determined that it has been optimally used to implement the BMW policy by Tulang Bawang Regency successfully.
\end{abstract}

Keywords: Implementation of Community Policy, Moving to Serve Citizens, Public Services.

\section{A. INTRODUCTION}

Forming a government is to maintain an order system where people can live everyday life. Therefore, the government is essentially a service to the community and must serve the community, creating conditions that allow every member of society to develop their abilities and creativity to achieve mutual progress (Hodges et al., 1996; Dwimawanti, 2004; Wibawa, 1994). According to Ndraha (2011), as a public work unit, the government works to meet and protect the needs, interests and demands of those ruled as consumers and sovereigns, for public services and civil services, in government relations. The 1945 Constitution has also mandated that the state be obliged to serve every citizen and population to fulfill their basic rights within public services.

Because of its orientation towards the public or the people, the state tries in such a way as to serve its people. If the people served the state or government in the past, now the government or form is the people's servant (Denhardt \& Denhardt, 2000; Hardiyansyah, 2018; Hamirul, 2018). The occurrence of this paradigm shift, apart from the demands of society, democracy in various fields of life, including requests for decentralization or regional autonomy (for the case in Indonesia), changes and advances in information technology, communication technology, and 
transportation technology, is also inseparable from changing paradigms itself (Sudrajat, 2009; Setijaningrum, 2011; Herizal et al., 2020)

However, changing the orientation to the people is not an easy thing. Changing the mindset and habit of being "served" by the government to "serving" takes a long time. However, we also do not close our eyes that today, with the Head of State's election to the Head of the Region directly by the people, the paradigm of wanting to be "served" has changed a lot towards "serving". The narratives of various visions, missions, work programs of the Head of State or Regional Heads have now shown a lot of service orientation to the community (Karningsih, 2019; Dolongseda et al., 2017).

Public services are the most visible measure of the government's performance. The public can directly assess government performance based on the quality of public services received, because the quality of public services is felt by the people from all walks of life, where success in building public service performance in a professional, effective, efficient and accountable manner will raise the positive image of the government in the eyes of its citizens (Dwiyanto, 2001; Wirijadinata, 2020).

Responsiveness is the most crucial dimension of the quality of public services that requires more attention and attention by government agencies (Suwarsito \& Aliya, 2020; Chrismastianto, 2017). Also, a significant element in influencing public services is related to timeliness by government employees in serving people who have knowledge and abilities following their work (Puspitawati \& Riana, 2014; Susila, 2014).

Tulang Bawang Regency is one of the districts in Lampung Province. The area of Tulang Bawang Regency is 3,466.32 $\mathrm{km}^{2}$. Dente Teladas Subdistrict is the largest sub-district with an area of $685.65 \mathrm{~km} 2$ or 19.78 per cent of Tulang Bawang Regency. Meanwhile, Meraksa Aji District has an area of $94.71 \mathrm{~km} 2$ or 2.73 per cent of Tulang Bawang Regency. Tulang Bawang Regency's location consists of 15 sub-districts with 147 villages and 4 sub-districts, 828 Rukun Warga (RW), and 3277 Rukun Tetangga (RT).

Tulang Bawang Regency's vision for 2017-2022 is: "The realization of Safe, Independent and Prosperous Onion Bones". To realize this vision, the missions outlined for the development of Tulang Bawang Regency for the next 5 (five) years are: (1) Increasing equitable infrastructure development; (2) Improving the quality of education at all levels; (3) Increasing the reach of excellent health services; (4) Improve the community economy; (5) Reducing unemployment and poverty rates; (6) Increase and develop religious and cultural institutions; (7) Realizing quality, clean, transparent, easy, fast and pro-people governance with a strong spiritual basis; (8) Increasing access to and quality of education, health and regional infrastructure services; (9) Improving the quality of harmony, peace and community religion; (10) Increasing regional competitiveness, regional synergy and the development of a prosperous and independent village.

The leadership innovation outlined in the vision and mission is expected to realize effective and efficient public services, especially in Tulang Bawang Regency. 
Increasing public service is the extent to which the performance of all existing stakeholders can be implemented optimally. Therefore, the role of a leader is vital to influence others in achieving these goals. To achieve this goal, currently Tulang Bawang Regency through programs/activities to improve public service excellence has issued a Mobile Service Program Policy to Serve Citizens (BMW) which was implemented by the Bone Bawang Regency Government from 2017 to 2020 under the leadership of the Regent Tulang Bawang Winarti which contained in the Regional Medium-Term Development Plan (RPJMD) Tulang Bawang for 2017-2022, with the source of funds from the Regional Revenue and Expenditure Budget (APBD) of Tulang Bawang Regency.

Improving the quality of public services to enhance organizational performance can be achieved through government leadership with a new paradigm with innovative principles. For an organization to run effectively, an innovative leader must carry out two main functions: a task-oriented function and a group maintenance function in the form of public services policies. In this case, the implementation of the Moving Serve Citizens (BMW) policy has never been studied before. Effective and efficient forms of policy in public services have never been identified before

Based on the description above, the authors are interested in researching with the title: "Implementation of Mobile Policy to Serve Residents in Tulang Bawang Regency (Public Service Innovation Study)". This study identifies, analyzes, and explains moving policies' implementation to serve citizens in realizing effective and efficient public services in Tulang Bawang Regency.

\section{B. METHODS}

Research on the implementation of mobile policies to serve residents in Tulang Bawang Regency (the study of public service innovation uses a mixedmethod research type or often referred to as a mixed-method, which is a research approach that combines or associates qualitative and quantitative forms with inductive-deductive thought processes, namely by studying something general then abstracts it into a particular form, the specific state is then extracted into a more general condition based on a theory that is following the phenomenon and research needs (Effendy, 2010).

Mixed research is a procedure for collecting, analyzing, and mixing quantitative and qualitative methods in a study or series of studies to understand research problems (Creswell \& Creswell, 2017). This is in line with (Johnson \& Christensen, 2019) that mixed research is a class of research studies in which researchers mix or combine quantitative and qualitative research approaches and techniques in a single research study. This research is useful for describing complex phenomena and can see comparisons between cases. This research can analyze the combined results of quantitative and qualitative research so that the data will be more precise and complementary. 
In connection with this paper's research, the researcher used mixed research with a sequential explanatory method. The sequential descriptive process is applied by collecting and analyzing quantitative data in the first stage, followed by the collection and analysis of qualitative data in the second stage built on the initial quantitative results. The first thing the researcher needs to do to get this data by using quantitative research can provide an overview of the policy "Move to Serve Citizens" for service effectiveness through public service innovation. After obtaining the above data, the researcher continues qualitative research to conduct a more indepth exploration of this topic. Therefore, this mixed research design uses a sequential explanatory strategy. This research design intends to find out data based on quantitative results and explore more profoundly using qualitative data.

\section{RESULT AND DISCUSSIONS}

\section{Quantitative Analysis}

The implementation variable of this policy consists of 3 indicators, namely improving public service agency (BMW-IPS), response public service (BMW-RPS), The development of autonomous village (BMW-DAV) and Improving Public Service Infrastructures \& Facilities (BMW-IIS). Which is considered to determine the success of implementing the policy of moving to serve residents in Tulang Bawang Regency. 23 items of questionnaire questions measure this variable.

Based on each variable's average score, the results show that the variable implementation of the moving policy to serve citizens is generally classified as useful with a score of 620 . If it is concluded that in general the performance of BMW policies that have been carried out so far, although it has been good, still has to be improved so that the quality of public services is of higher quality. . Each indicator of this variable is considered to determine the success of the policy objectives. This means that the policy targets that have been set have been optimally used to implement the BMW policy by Tulang Bawang Regency successfully. The optimal implementation of policy standards and targets is because they are used as benchmarks but are consistently applied or policy standards and targets are quite ideal at the policy implementer level.

It's just that to measure BMW policy implementation; of course, it is necessary to use specific standards and targets that must be achieved by policy implementers. Policy performance is an assessment of the level of achievement of these standards and targets. Therefore, understanding the general intent of standard and policy objectives is essential. Successful implementation of policies may fail (frustrated) when officials are not fully aware of the standards and policy objectives. Standard and policy objectives have a close relationship with the disposition of the implementers. The direction of the implementers' disposition (implementors) against standards and policy objectives is also a "crucial". Implementors may fail in implementing the policy because they reject or do not understand the policy's goal.

This study indicates that most respondents (61.5 per cent) consider that the overall public service is in a suitable category. There are even 58 respondents or 36.2 
per cent who think that public services are excellent. Meanwhile, only 5 people or 3.1 per cent of respondents gave low ratings on public services quality. Different assessments that differ from respondents, including bad ratings are closely related to the opinion of Triguno (1997) which states that "the best servant, is to serve at any time, quickly and satisfactorily, be polite, friendly and helpful, and professional and capable", thus service that does not show politeness, friendliness and indifference will illustrate the lack of empathy of a servant. In particular, most assessments are good and very good compared to preliminary estimates, showing that the Tulang Bawang Regency Government's BMW program through public services has been well received and felt by the residents of Tulang Bawang Regency. However, a small part of the community who use services stated that they were not satisfied by giving bad ratings against what he has received.

The test results of the effect of implementing the "Move to Serve Citizens" (BMW) Policy on Public Services, the path of this influence relationship is significant at $5 \%$ because the T-Statistic value is above the $t$ table value of 1.96 . Likewise, the PValue is at the P-Value significance level $<0.05$, so the test value of the effect of BMW Policy Implementation on Public Services is obtained with a T-Statistic value of 5.685 which is significant at $5 \%$ because it is above the $t$ table 1 value. 96 . Likewise, the PValue value of 0,000 is at the P-Value significance level $<0.05$ and the effect coefficient value is $64.2 \%$. Because the P-Value $<0.05$, thus to test the effect of the Implementation of the "Move to Serve Citizens" (BMW) Policy on Public Services, the conclusion is that there is a significant effect of BMW Policy Implementation on Public Services in the District Government of Tulang Bawang.

\section{Qualitative Analysis}

Implementing the "Moving to Serve Citizens" (BMW) policy in Tulang Bawang Regency, which is now being implemented, has entered its second year and has reaped some results. The initial initiator of the BMW Policy with a centralized service system in the Public Service Mall was the current Regent, a flagship program for public and political interests. The decision-making process for BMW and MPP policies is more influenced by the Regent's existing political will so that the interactive process is not known to the public.

The involvement of public policy actors in terms of power, interests and strategies was initially more dominant in the elected Regent's initiative than the industry of the legislature based on input on public issues. If examined from the interactive model of policy implementation according to Dye (1978), the dominance of the elected Regent's initiative in carrying out the initiative program of the elected Regent, namely serving as a particular political program, will, of course, affect the use of resource inputs. If there is no positive and dynamic interaction in policy implementation (in this case, the MPP service program) between policymakers and policy users, the use of resource inputs is not optimal.

The implementation goal is embodied in the MPP service program. The impact of changing the service model is the effectiveness and efficiency of services, 
including service program management costs. Service program costs can be efficient if there is a commitment from the leadership that transmits the values of work culture to the staff and there is a work commitment of the team in implementing service programs according to the vision, mission and objectives of the program, based on the real conditions of work costs in the program being implemented. This finding is consistent with the elements of the policy implementation model put forward by Grindle (1980), which suggests that resource commitment is also an element that influences program implementation activities. Another logical consequence is the need for incentives to reward the performance results and work commitments possessed by leaders and service office staff.

The Public Service MAL Office (MPP) in Tulang Bawang Regency also has a complaint unit in the form of an SMS centre, internet and a suggestion box that is in front of the office building, as observed. Of the three service complaint facilities, the most frequently used facilities were SMS (99\%) and suggestion box (1\%), were in the year there were only 8 complaints boxes. The existence of a complaint service (complaint centre) when examined from the policy implementation model proposed by Grindle (1980), complaint service is an absolute thing considering that there needs to be an element of influential interests in the policy's content. This complaint service is essential to improve services on an ongoing basis. To socialize the BMW program and MPP services, the Regent conducts outreach to all villages. This is also to strengthen the implementation of the BMW program and MPP services. In the policy implementation model proposed by Grindle (1980), the Regent's service program socialization has one of the characteristics of the policy content factor, in terms of broadening the insight into change. This also concerns the location of decision making (site of decision making) within the scope of the Regent's leadership as the executor of regional development programs, including service programs.

The quantitative research results show that implementing the "Move to Serve Citizens" (BMW) policy is suitable. Qualitatively, this is the case. Another thing that was revealed in the interview was that apart from getting a positive response from residents who had benefited from this policy, several informants stated that there were still obstacles to implementing this policy. Behind the perceived constraints, the informant said that the local government had taken steps to anticipate the obstacles they felt. Based on the data above, it appears that the reasons for implementing the BMW policy in Tulang Bawang Regency have been in line with several expert opinions regarding the definition of public policy itself, especially when it is related to the formulation conclusions of several purposes of public policies which state that: "Public policy can be interpreted as things "things the government decides to do or do and things the government decides not to do or ignore".

Likewise, the implementation of the 2017-2024 TULANG BAWANG RPJMD RANPERDA, the BMW flagship program mentioned above, is a positive step in the development of 5 (five) years that will benefit the people of Tulang Bawang Regency. The public's policy is a result of a comprehensive, integrated and 
integrated and in-depth analysis of various alternative options that produce the best decision-making on public problems.

Based on this, it appears that the steps taken by the District Government of Tulang Bawang in this case to implement this policy are the right steps considering that the approaches taken by the government are decisions to take over part of the burden on its citizens at the same time to overcome or minimize the problems faced by the community related to their welfare.

Regarding the steps to implement the BMW policy by the District Government of Tulang Bawang, it seems that it is in line with or following several models in implementing public policies.

First, conformity to the George C Edward III Model. This conformity is seen through communication activities in the form of socialization, involvement of internal and external resources through cooperation in program management, as well as strengthening the desire and attitude of managers, especially the Regional Head as the leading sector in the successful implementation of BMW policies in terms of essential public services and bureaucratic structures, primarily through relationships. between offices to implement BMW policies and to disseminate widely to the public or other partners (Edward, 1980)

Second, compatibility with the model of Daniel Mazmanian and Paul A. Sabastier. The suitability of the three variables classified by Daniel Mazmanian and Paul A. Sabastier in Solichin A. Wahab (1997: 65) is evident in the implementation of BMW policy, especially when it is linked to independent variables with the consideration of whether or not the problem is easy to control over the performance of the policy. With the ability of local governments to structure the implementation process and the ability of local governments to integrate hierarchies among implementers, including in terms of recruiting implementing officials. Meanwhile, the dependent variable's suitability can be seen in the steps taken by the local government of Tulang Bawang to provide understanding to all employees, stakeholders and the Tulang Bawang community in the framework of implementing the policy.

Third, compatibility with the Merilee S Grindle model. According to this model, the success of policy implementation is determined by implementing a policy. For this reason, every policy according to Merilee S Grindle must contain: (1) the interests affected by the policy, (2) the types of benefits to be generated, (3) the degree of change desired, (4) the position of the policymaker, (5) who is the implementer program, and (5) the resources deployed. The suitability of the content intended by the Merilee S Grindle appears to be implied and express in BMW's policy.

Furthermore, the research results are directed to confirm the prerequisite for choosing which model is appropriate for local governments' implementation of a policy. The precondition in question is to consider the "four right" principle (Nugroho, 2006). The confirmation results show that the Bone Bawang Regency government's actions or steps in implementing BMW policies in public services 
conform. This also answers the second hypothesis of this study: the implementation of the "Move to Serve Citizens" policy has a significant effect on public services in Tulang Bawang Regency.

\section{CONCLUSION}

Implementation of the Policy on Serving Citizens to Public Services (Effectiveness of Public Services) in Tulang Bawang Regency has a big (significant) effect as indicated by the value of $t$-statistics $(5,685)>1.96$ and P-Value $(0,000)<0.05$. The research findings model is expected to be useful as a scientific contribution in the development of policy implementation-oriented towards optimal service to the community and to be further developed by researchers in conducting other similar research. The research findings model is expected to be useful as a scientific contribution in developing government leadership and implementing policies that are oriented towards optimal service to the community and further developed by researchers in conducting other similar research.

\section{REFERENCES}

1. Chrismastianto, I. A. W. (2017). Analisis SWOT Implementasi Teknologi Finansial Terhadap Kualitas Layanan Perbankan di Indonesia. Jurnal Ekonomi dan Bisnis, 20(1), 134-136.

2. Creswell, J. W., \& Creswell, J. D. (2017). Research design: Qualitative, quantitative, and mixed methods approach. Sage publications.

3. Denhardt, R. B., \& Denhardt, J. V. (2000). The New Public Service: Serving Rather than Steering. Public Administration Review, 60(6), 549-559.

4. Dolongseda, E., Gosal, R., \& Kimbal, A. (2017). Reformasi Birokrasi pada Dinas Kependudukan dan Pencatatan Sipil Pemerintahan Kabupaten Kepulauan Sangihe. Jurnal Eksekutif, 2(2).

5. Dwimawanti, I. (2004). Kualitas Pelayanan Publik. Jurnal Ilmu Administrasi dan Kebijakan Publik.

6. Dwiyanto, A. (2001). Penilaian Kinerja Organisasi Publik. Jurusan Ilmu Administrasi Negara, Fisipol UGM, Yogyakarta

7. Dye, T. R. (1978). Understanding Public Policy. Englewood Cliffs: Prentice-Hall.

8. Edwards, G. C. (1980). Implementing Public Policy. Washington, DC: Congressional Quarterly Press.

9. Effendy, K. (2010). Memadukan Metode Kuantitatif dan Kualitatif. Bandung: Indra Prahasta.

10. Grindle, M. S. (1980). Politics and Policy Implementation in The Third World. New Jersey: Princeton University Press.

11. Hamirul, H. (2018). Patologi Pelayanan Publik di Era Revolusi Industri 4.0. Jurnal Ilmiah Tata Sejuta STIA Mataram, 4(2), 1-16.

12. Hardiyansyah, H. (2018). Kualitas Pelayanan Publik: Konsep, Dimensi, Indikator dan Implementasinya. Gava Media. 
13. Herizal, H., Mukhrijal, M., \& Wance, M. (2020). Pendekatan Akuntabilitas Pelayanan Publik dalam Mengikuti Perubahan Paradigma Baru Administrasi Publik. Journal of Governance and Social Policy, 1(1).

14. Hodges, R., Wright, M., \& Keasey, K. (1996). Corporate Governance in the Public Services: Concepts and Issues. Public Money E Management, 16(2), 7-13.

15. Johnson, R. B., \& Christensen, L. (2019). Educational research: Quantitative, Qualitative, and Mixed Approaches. SAGE Publications, Incorporated.

16. Karningsih, K. (2019). Demokratisasi Pelayanan Publik Di Indonesia. Mimbar Administrasi FISIP UNTAG Semarang, 16(19), 60-72.

17. Mazmanian, A. D., \& Sabatier, A. P. (1989). Implementation and Public Policy: With a New Postscript. University Press of America.

18. Ndraha, T. (2011). Kybernology (Ilmu Pemerintahan Baru) 2. Jakarta: Rineka Cipta.

19. Nugroho, R. D. (2003). Kebijakan Publik: Formulasi, Implementasi, Evaluasi. Jakarta : PT. Elex Media Komputindo Kelompok Gramedia.

20. Puspitawati, N. M. D., \& Riana, I. G. (2014). Pengaruh kepuasan kerja terhadap komitmen Organisasional dan kualitas layanan. Jurnal Manajemen Strategi Bisnis dan Kewirausahaan, 8(1), 68-80.

21. Sudrajat, T. (2009). Perwujudan Good Governance Melalui Format Reformasi Birokrasi Publik Dalam Perspektif Hukum Administrasi Negara. Jurnal Dinamika Hukum, 9(2), 145-154.

22. Susila, G. P. A. J. (2014). Implementasi Quality Function Deployment (QFD) untuk Meningkatkan Layanan Publik di RSUD Kabupaten Buleleng Bali. Jurnal Ilmu Sosial dan Humaniora, 3(2).

23. Suwarsito, S., \& Aliya, S. (2020). Kualitas Layanan dan Kepuasan Serta Pengaruhnya Terhadap Loyalitas Pelanggan. Jurnal Ilmiah Bina Manajemen, 3(1), 27-35.

24. Triguno. (1997). Budaya Kerja:Menciptakan Lingkungan Yang Kondusif Untuk Meningkatkan Produktivitas Kerja. Jakarta: Golden Terayon.

25. Wibawa, S. (1994). Kebijakan publik. Jakarta: Proses dan Analisis, Intermedia.

26. Wirijadinata, J. J. (2020). Standar Pelayanan Publik dalam Merealisasikan Akuntabilitas Kinerja Pemerintah. Jurnal Wacana Kinerja: Kajian Praktis-Akademis Kinerja dan Administrasi Pelayanan Publik, 10(4), 59-70. 